\title{
WHAT HAPPENS WHEN DEVELOPERS CAN'T DEVELOP: CAN AND SHOULD RESOURCE DEVELOPERS BE COMPENSATED WHEN THEY CAN'T DEVELOP THEIR ASSETS?
}

\author{
SHAWN H.T. DENSTEDT ${ }^{*}$ AND RYAN V. RODIER ${ }^{* *}$
}

This article considers the question of whether resource developers are entitled to compensation when their ability to exercise proprietary rights is effectively sterilized by government action, a phenomenon known as "de facto expropriation." It sets out the legal principles that have been applied by courts in Canada, the U.K., the U.S., and Australia. It discusses how courts have considered entitlement to compensation in this context, and how the quantum of compensation can be determined. It concludes that, absent some overriding public interest, the law supports compensating a party whose rights have been confiscated.

\begin{abstract}
Cet article examine la question de savoir si les agents d'exploitation des ressources sont admissibles à une indemnisation lorsque leur capacité d'exercer leurs droits de propriété, dans les faits, sont éliminés après une action du gouvernement, phénomène appelé « expropriation de fait ». L'article énonce les principes juridiques que les tribunaux du Canada, du RoyaumeUni, des États-Unis et de l'Australie ont appliqués. Il examine de quelle manière les tribunaux ont considéré le droit à l'indemnisation dans ce contexte, et comment on peut déterminer le montant de cette indemnité. Il conclut qu'en l'absence d'un intérêt dérogatoire du public, la loi est en faveur de l'indemnisation d'une partie dont les droits ont été confisqués.
\end{abstract}

\section{TABLE OF CONTENTS}

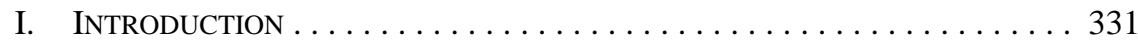

II. PROPERTY RIGHTS AND EXPROPRIATION $\ldots \ldots \ldots \ldots \ldots \ldots \ldots \ldots \ldots . \ldots \ldots$

III. THE DE FACTO EXPROPRIATION OF

NAtural Resource AsSets . . . . . . . . . . . . . . . . . . . . . . . 335

A. THE CANADIAN EXPERIENCE $\ldots \ldots \ldots \ldots \ldots \ldots \ldots \ldots$

B. THE U.K. EXPERIENCE . . . . . . . . . . . . . . . . . . . . . . . . . 342

C. THE U.S. EXPERIENCE $\ldots \ldots \ldots \ldots \ldots \ldots \ldots \ldots \ldots \ldots \ldots \ldots \ldots \ldots$

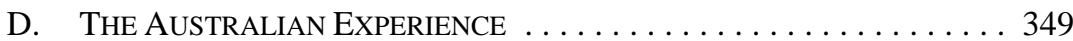

IV. COMPENSATION FOR THE DE FACTO EXPROPRIATION

of Natural Resource AsSets . . . . . . . . . . . . . . . . . . . . . . . . 352

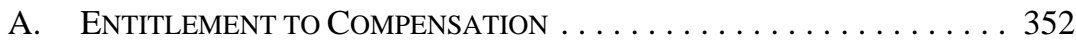

B. Determining THE AMOUNT OF COMPENSATION . . . . . . . . . . 353

V. A PRINCIPLED APPROACH TO ESTABLISH COMPENSABLE

DE FACTO EXPROPRIATIONS ... . . . . . . . . . . . . . . . . . . 357

\section{INTRODUCTION}

The right to property is notably absent from Canada's Constitution, yet our market-based economy and legal system are based on the premise that property rights, including natural resource interests, have value and deserve legal protection. Property rights are protected by both the common law and legislation. When property is expropriated by government, regulatory schemes and legislation often provide for a right to compensation.

* $\quad$ Q.C., Partner, Osler, Hoskin \& Harcourt LLP, Calgary, Alberta.

Associate, Osler, Hoskin \& Harcourt LLP, Calgary, Alberta. The authors wish to extend a special thanks to Jessica Ng of Osler, Hoskin \& Harcourt LLP for her extensive and exceptional assistance in preparing this article. 
Increased regulatory oversight may give rise to situations where government takes an action that, while not a formal acquisition of a proprietary interest equating to expropriation, nevertheless regulates a proprietary interest to such an extent that a developer's ability to exercise its rights is effectively sterilized. That is, there is a point at which government regulation is tantamount to expropriation. This phenomenon is known as "de facto expropriation," "1 and raises the question of whether resource developers are protected from such government action and entitled to compensation for de facto expropriation.

To determine if resource developers have a remedy against de facto expropriation, the nature of property rights and the basics of expropriation law must first be explored. Within that context, the legal principles underpinning de facto expropriation are set out, as well as how these principles have been applied in Canada, the U.K., the U.S., and Australia. Included in this discussion is how courts have considered entitlement to compensation in the context of de facto expropriation, and how the quantum of compensation can be determined. Finally, this article concludes that a principled application of the criteria articulated in court decisions should support credible compensation claims arising from the sterilization of natural resource interests due to government regulation. This conclusion is based on the premise that natural resource rights have value, and that parties have a reasonable expectation that those rights can be exercised. Absent some overriding public interest, the law supports compensating a party whose rights have been confiscated.

\section{Property Rights AND EXPROPRIATION}

To understand what rights attach to property, the very nature of property must be considered. Every day we encounter property and the rights that come with it in different guises and forms. Property can be defined in a number of ways, but essentially it is " $t$ the right to possess, use, and enjoy a determinate thing” such as a tract of land or a chattel. ${ }^{2}$ Property is also referred to as a "bundle of rights," which is a collection of entitlements created by law enforceable against others. These bundles of rights have value, which is why they can be bought and sold. The fact that property has value is also why it represents a loss to the property interest owner when the bundle of rights cannot be exercised.

Different types of natural resource interests support different bundles of rights. A licence is not an interest in land and is merely the permission to do what is otherwise wrongful, and typically does not bind subsequent purchasers of the land over which the licence is exercised. ${ }^{3}$ A lease, which is an interest in land, provides for a greater entitlement involving a grant of exclusive possession. ${ }^{4}$

It is a well-established common law principle that a right to mines and minerals includes the right to do all things necessary to work and recover the minerals. The extent of the rights of a mineral owner to enter, win, and work minerals depends on the terms of the instrument taking" are also used to describe the same concept. Canadian courts have used the term "de facto expropriation" and that is the term used in this article.

Black's Law Dictionary, 9th ed., s.v. "property."

Bruce Ziff, Principles of Property Law, 4th ed. (Toronto: Carswell, 2006) at 293.

Ibid. at 270 . 
of severance. ${ }^{5}$ Where the rights of access and work are uncertain or absent in the instrument of severance, they will be implied. In Rowbotham, the House of Lords stated: "Prima facie, it must be presumed that the minerals are to be enjoyed, and, therefore, that a power to get them must also be granted or reserved, as a necessary incident." ${ }^{6}$ This was subsequently adopted by Borys v. Canadian Pacific Railway, ${ }^{7}$ which remains the leading authority in Canada for this proposition. The Alberta Court of Appeal confirmed that an implied right to work minerals arises from reservations, grants, and leases — including Crown leases — in Alberta Energy Co. v. Goodwell Petroleum Corp. Ltd. ${ }^{8}$

An oil and gas lease in Alberta, whether private or Crown, is not "a lease in the normal sense of the term," but a profit à prendre. ${ }^{9}$ The holder of the profit à prendre does not own the natural resources in situ, but owns natural resource claims and "the right to exploit them through the process of severance." 10 A profit à prendre is "a right to enter on the land of another person and take some profit of the soil such as minerals, oil [or] stones ... for the use of the owner of the right." 11 This includes the right to use the surface, search for, and win the substances as is necessary and convenient to exercise the profit. ${ }^{12}$ However, this does not preclude the surface owner from exercising their own rights and the mineral owner may be liable for damages to the surface owner's crops, orchards, buildings, and fences caused by their operations. ${ }^{13}$ The common law principles governing the right to access mines and minerals were succinctly summarized by the Alberta Court of Appeal in Goodwell:

1. A right to mines and minerals includes the right to work, dig and use all reasonable means to recover the minerals.

2. If mining and recovering the minerals results in a known and inevitable consequence, that consequence is construed to be an implied term, and holders of lands or other mineral rights affected by that consequence cannot enjoin mining and recovery of the minerals.

3. These principles apply to reservations of mineral title, as well as grants and leases, including crown leases. Otherwise, the mineral right would be useless, and, as a general rule, deeds should not be construed to be without effect if other equally defensible interpretations are available.

4. While a bare right to a mineral conveys a right to win, work and carry away the mineral, that power can be expanded or restricted by express wording in the deed.

Rowbotham v. Wilson (1860), 11 E.R. 463, 8 H.L. Cas. 348 at 360 [Rowbotham].

Ibid.

[1953] A.C. 217 (P.C.).

2003 ABCA 277, 399 A.R. 201 at para. 64 [Goodwell].

Berkheiser v. Berkheiser, [1957] S.C.R. 387 at 391-92; ibid. at para. 63, citing Bank of Montreal v. Enchant Resources Ltd., 1999 ABCA 363, 255 A.R. 116 at para. 53.

R. v. Tener, [1985] 1 S.C.R. 533 at para. 13 [Tener].

Cherry v. Petch, [1948] O.W.N. 378 at 380 (H.C.J.) [Cherry].

Tener, supra note 10 at para. 12; Hamilton Brothers Corp. v. Royal Trust Corp. of Canada (1991), 113

A.R. 321 at para. 27 (Q.B.), aff'd on other grounds, 117 A.R. 314 (C.A.).

Cherry, supra note 11 at 382. 
5. Relevant statutes, including conservation rules arising from statutes, may modify these principles. ${ }^{14}$

As indicated in Goodwell, property rights are not absolute and can be subject to restrictions. There are circumstances where privately owned property may be needed for public purposes. In such cases, the government often has the authority to confiscate or expropriate the property without the owner's consent. Without this government authority to expropriate, the public interest could effectively be trumped by an individual property owner's refusal to consent. Nevertheless, expropriation is an infringement of private property rights, and basic principles of fairness and justice require protections to be put in place to ensure that government expropriation is not exercised in an arbitrary manner. This tenet of law dates back to the Magna Carta of 1215, which recognized that the King should not dispossess any man of lands and castles "without the lawful judgement of his equals."15 When property interests are expropriated by government, property owners are forced to bear a burden for the sake of the public interest. Compensating an owner for the loss of their property simply shifts the cost of the public benefit back to the public purse.

A Canadian property owner's entitlement to compensation for expropriation is shaped by the fact that property rights are not constitutionally entrenched. While the Canadian Bill of Rights protects the "enjoyment of property, and the right not to be deprived thereof except by due process of law,"16 this protection is limited because the Bill of Rights only applies to the federal government. ${ }^{17}$ Furthermore, this right can be repealed by subsequent legislatures, and the requirement for "due process of law" must only satisfy procedural fairness and does not guarantee a substantive right to compensation. ${ }^{18}$ Additionally, the Canadian Charter of Rights and Freedoms ${ }^{19}$ is silent with respect to the right to property and other economic rights. ${ }^{20}$ This lack of constitutional protection for property rights has led some to conclude that foreign investors in Canada may be entitled to stronger protections against de facto expropriation under international trade agreements than Canadian property owners (for example, the North American Free Trade Agreement Between the Government of Canada, the Government of Mexico and the Government of the United States $\left.{ }^{21}\right)^{22}$

Supra note 8 at para. 64 .

Magna Carta (1215), cl. 52, online: British Library <http://www.bl.uk/treasures/magnacarta/translation/ mc trans.html>.

S.C. 1960 , c. 44 , s. 1(a) [Bill of Rights].

Ibid., s. 5(3).

Bryan P. Schwartz \& Melanie R. Bueckert, "Regulatory Takings in Canada” (2006) 5 Washington University Global Studies Law Review 477 at 479.

Part I of the Constitution Act, 1982, being Schedule B to the Canada Act 1982 (U.K.), 1982, c. 11 [Charter].

This omission was intentional because drafters of the Charter feared that Canadian courts would use property rights to block social welfare legislation: Schwartz \& Bueckert, supra note 18 at 479-80.

17 December 1992, Can. T.S. 1994 No. 2, 32 I.L.M. 289 (entered into force 1 January 1994) [NAFTA]. Russell Brown, "Legal incoherence and the extra-constitutional law of regulatory takings: The Canadian Experience" (2009) 1 International Journal of Law in the Built Environment 179 at 185-86. In a recent example, regulators refused to issue the necessary authorizations for a proposed basalt quarry and marine terminal in Nova Scotia after a joint federal-provincial environmental assessment review panel recommended that the project was likely to cause significant adverse environmental effects that could not be justified. U.S. investors subsequently filed a claim under NAFTA, ibid., alleging that they were treated less favourably than Canadian investors in like circumstances (art. 1102), that they were treated in an unfair, arbitrary, and discriminatory manner (art. 1105), and that they had not been accorded treatment no less favourable than that provided to foreign investors under other international agreements to which Canada is a party (art. 1103). The arbitration is still underway. The legal documents related to Bilcon of Delaware v. Canada can be found online: Foreign Affairs and International Trade Canada <http://www.international.gc.ca/trade-agreements-accords-commerciaux/disp-diff/clayton_archive. aspx?lang=en $>$. Article 1110 of NAFTA also provides for mandatory compensation for measures 
In Canada, both the authority to expropriate and the right to compensation due to expropriation must be grounded in statute. ${ }^{23}$ Statutes authorizing expropriation will sometimes explicitly provide for compensation. Canada and each of the provinces and territories also have their own expropriation statutes outlining the compensation process for the expropriation of interests in land. ${ }^{24}$ Government also has the ability to pass legislation that excuses itself totally from liability for expropriation. ${ }^{25}$ Some measure of protection is provided in the common law, where courts have adopted a presumption in favour of compensation unless statutes expressly provide otherwise. The most oft-cited articulation of this presumption can be found in Attorney-General v. De Keyser's Royal Hotel Ltd.: "[U]nless the words of the statute clearly so demand, a statute is not to be construed so as to take away the property of a subject without compensation."26

It is clear that property has value in our society. When property is sold, the property owner receives compensation for the value of that property. When property is lost or stolen, so too is the value of that property to the rightful owner. When property is taken by government (even for the public good), unless compensation is paid for the taking, the owner of the property experiences a loss of its associated value and, arguably, an unjust enrichment accrues to the public.

\section{The De FACTo EXPRopriation of NATURAL RESOURCE AsSETS}

Restrictions on private property interests through government regulation are an ordinary feature of civilized society. The regulation of land use zoning, the environment, public health, safety, welfare, and revenue will inevitably have varying impacts on private property interests. In order for society to function properly, the government must be able to restrict private property rights in ways that are not compensable. Otherwise, the expectation of compensation for every diminution of property rights could result in prohibitive financial consequences that inhibit effective government regulation. The courts have clearly stated that a mere negative prohibition that interferes with an owner's enjoyment of property does not carry a common law right to compensation. ${ }^{27}$

Government regulation can restrict the use of a proprietary natural resource interest to such an extent that it is effectively confiscated or expropriated, even though the developer retains formal ownership of the interest. In Canada, the courts have referred to this as "de

tantamount to the expropriation of foreign investments. For a discussion of de facto expropriation claims under NAFTA, see Raymond E. Young, "A Canadian Commentary on Constructive Expropriation Law Under NAFTA Article 1110” (2006) 43 Alta. L. Rev. 1001; Bruce Ziff, “'Taking’ Liberties: Protections for Private Property in Canada” in Elizabeth Cooke, ed., Modern Studies in Property Law (Portland, Or.: Hart, 2005) vol. 3, 341.

23 Eric C.E. Todd, The Law of Expropriation and Compensation in Canada, 2d ed. (Toronto: Carswell, 1992) at 25-26.

24 See e.g. Expropriation Act, R.S.C. 1985, c. E-21; Expropriation Act, R.S.A. 2000, c. E-13; Expropriation Act, R.S.B.C. 1996, c. 125; Expropriations Act, R.S.O. 1990, c. E-26; Expropriation Act, R.S.N.W.T. 1988, c. E-11.

25 See e.g. Coalbed Gas Act, S.B.C. 2003, c. 18, s. 6; Metis Settlements Act, R.S.A. 2000, c. M-14, s. 237; Ontario Heritage Act, R.S.O. 1990, c. O-18, s. 68.3.

[1920] A.C. 508 at 542 (H.L.) [De Keyser], cited in Manitoba Fisheries Ltd. v. R., [1979] 1 S.C.R. 101 at 109 [Manitoba Fisheries].

France Fenwick and Company Ltd. v. R., [1927] 1 K.B. 458 at 467. 
facto expropriation., ${ }^{28}$ The question then becomes: when government restricts property rights, how does one distinguish between a mere negative prohibition that may not warrant compensation, and a de facto expropriation where compensation may be payable? A review of case law in Canada, the U.K., the U.S., and Australia provides some guidance on what is currently considered a compensable de facto expropriation, though the principles and their application are not always consistent among, and even within, jurisdictions.

\section{A. The CANAdian EXPERIENCE}

In Canada, successful compensation claims for de facto expropriations are rare. Canadian courts have established the following legal principles:

(1) A property interest involves a "bundle of rights."

(2) Some of the rights in the bundle may be restricted by government regulation.

(3) Restrictions through government regulation will constitute a de facto expropriation where two criteria are met:

(a) First, the regulation results in government acquiring a beneficial interest in the property, or a benefit flowing from it; and

(b) Second, the regulation results in a removal of all reasonable uses of the property interest.

(4) An owner of a property interest that was subjected to de facto expropriation is presumed to be entitled to compensation unless there is an express statutory abrogation of compensation.

\section{SuCCESSFUl DE FACTO EXPROPRIATION Claims}

De facto expropriation was first recognized by the Supreme Court of Canada in Manitoba Fisheries. ${ }^{29}$ The claimant owned and operated a profitable fish exporting business for over 40 years until the enactment of federal legislation that gave a Crown corporation the exclusive right to carry on the business of fish exporting. All other firms in the industry were prohibited from carrying on their business of fish exporting unless a licence or exemption was granted. No licence or exemption was issued to the claimant and it was conceded that implementing the legislation had the effect of putting the claimant out of business. ${ }^{30}$ The legislation left the claimant's suppliers and customers with no choice but to do business with the Crown corporation. While the legislation provided for arrangements to compensate owners of plants or equipment that might be rendered redundant by the statutory monopoly, the government still refused to compensate the claimant.

For example, the term "de facto expropriation" is used in Alberta (Minister of Public Works, Supply \& Services) v. Nilsson, 1999 ABQB 440, 246 A.R. 201 [Nilsson]; Mariner Real Estate Ltd. v. Nova Scotia (Attorney General) (1999), 178 N.S.R. (2d) 294 (C.A.) [Mariner Real Estate]. 
The Court held that the legislation had the effect of taking away the claimant's goodwill (that is, the reputation and connections of a business) such that it was constructively acquired by the Crown corporation. ${ }^{31}$ Although the claimant retained its physical assets, those assets had been rendered virtually useless. The Court concluded that because there was nothing in the legislation expressly providing for the taking of property without compensation (that is, the presumption of compensation was not rebutted), the claimant was therefore "entitled to compensation in an amount, equal to the fair market value of its business ... minus the residual value of its remaining assets" after the de facto expropriation. ${ }^{32}$

Manitoba Fisheries clearly meets the requirements of a de facto expropriation. First, the government had acquired a direct benefit by effectively legislating the claimant out of business and then filling the role previously held by the claimant. Second, all reasonable uses of the property interest had been removed because the claimant was forced to discontinue its business, and was thereby deprived of its goodwill rendering its remaining physical assets "virtually useless." 33 Manitoba Fisheries also provides an example of the Court taking a broad view of "property" by considering an intangible interest such as goodwill to be a property interest.

Tener $^{34}$ is the classic example of de facto expropriation in the natural resource context. The claimants owned Crown-granted mineral claims in an area that was later designated a provincial park. Under the British Columbia Park Act, a park use permit had to be obtained before a natural resource in a provincial park could be exploited. ${ }^{35}$ The regulation of exploration and extraction of minerals became more stringent until, finally, a letter from the Director of the Parks Branch explicitly advised that "no new exploration or development work [respecting mineral claims] may be authorized within a Provincial Park.”36 Justice Estey, writing for the majority in the Supreme Court of Canada, confirmed that ordinarily "compensation does not follow zoning either up or down," ${ }^{37}$ but in this case a compensable de facto expropriation had occurred:

The denial of access to these lands occurred under the Park Act and amounts to a recovery by the Crown of a part of the right granted to the respondents in 1937. This acquisition by the Crown constitutes a taking from which compensation must flow. ${ }^{38}$

Justice Estey also noted that this taking enhanced the value of the public park, which is distinguishable from zoning regulations, regulation of activities on lands, and fire limits that in the Court's view do not add value to public property. ${ }^{39}$ Justice Wilson, concurring in the result, observed that the acquisition also benefited the Crown because it "effectively removed [an] encumbrance from its land." ${ }^{40}$ Justice Wilson also found that the refusal of the necessary

Ibid. at 118 .

Ibid.

Ibid.

Supra note 10.

S.B.C. 1965, c. 31, s. 18.

Supra note 10 at para. 4.

Ibid. at para. 49.

Ibid. at para. 59.

Ibid. at para. 60.

Ibid. at para. 37. 
permits had the effect of defeating the claimant's entire interest in the land and constituted an expropriation. ${ }^{41}$

Tener takes a broader view of the type of "beneficial interest" that can be acquired by the government in a de facto expropriation. References are made to a "recovery by the Crown" of the mineral claims, but there are indications that the Crown also benefited through the enhanced value of the public park and removal of an encumbrance..$^{42}$ This suggests that the benefit acquired by government can be different in substance than the specific property interest that is effectively confiscated (that is, the "benefit" obtained flows from the prohibition of a particular activity for the benefit of the public, and not from acquiring mineral claims). Tener also confirms that a de facto expropriation requires a total barrier to the exercise of a proprietary interest. Although the Crown-granted mineral claims remained with the claimants and had not been formally rescinded, the claimants had been prevented from using and enjoying their entire "bundle of rights" in the mineral claims.

Similar to Tener, other successful claims for de facto expropriation in Canada also involve an effective confiscation of mineral claims in provincial parks through regulation by government. In Casamiro Resource Co. v. British Columbia (A.G.), ${ }^{43}$ the British Columbia Court of Appeal held that the Order in Council barring the issuance of resource use permits for mineral exploration in a provincial park had reduced the claimant's rights under Crowngranted mineral claims to "meaningless pieces of paper," amounting to a de facto expropriation requiring compensation. ${ }^{44}$ In other words, all reasonable uses of the property interest had been removed. The Court did not explicitly address what kind of beneficial interest had been acquired by the Crown. The nuance in Casamiro is the fact that the mineral claims were granted after the establishment of the provincial park, but 40 years before the Order in Council was put in place. The affirmative finding of de facto expropriation indicates that, despite the prior park designation, the mineral claims still had reasonable uses that could be confiscated.

In Rock Resources Inc. v. British Columbia ${ }^{45}$ the British Columbia Court of Appeal also found that a de facto expropriation of mineral claims had occurred in an area that was subsequently designated a provincial park. The effect of the relevant legislation was to prevent the claimant from exploring for, or developing, minerals in certain parts of two mineral claim areas falling within the newly designated park's boundaries ${ }^{46}$ Even before the park designation, the claimant's mineral claims were contingent on the prior authorization of the Lieutenant Governor in Council, but the Court held that this did not change the fact that such rights had value that could be confiscated. ${ }^{47}$ The Court's conclusion implies that, based on the regulatory regime in existence when the mineral claims were granted, the claimant could reasonably expect that the minerals could be exploited. The exploitation of

Ibid. at paras. 34, 37.

Ibid. at para. 59.

(1991), 80 D.L.R. (4th) 1 (B.C.C.A.) [Casamiro].

Ibid. at 11.

2003 BCCA 324, 229 D.L.R. (4th) 115 [Rock Resources], leave to appeal to S.C.C. refused, [2004] 1

S.C.R. xiii.

Ibid. at para. 1.

Ibid. at para. 48. The value of the rights under the mineral claims was evidenced by the substantial consideration the claimant had provided for them and the fact that companies holding such claims trade shares publicly on the Canadian Venture Stock Exchange. 
minerals was therefore a "reasonable use" of the claimant's property interest that was removed by the provincial park designation. The Court did not discuss the need for the Crown to acquire a beneficial interest, but did cite Tener extensively.

\section{UNSUCCESSFUL DE FACTO EXPROPRIATION CLAIMS}

Unsuccessful de facto expropriation claims provide further insight into how courts have applied the legal principles regarding this issue. These decisions confirm that a loss of either economic value or partial use in a proprietary interest will not support a claim of de facto expropriation because there has not been a removal of "all reasonable uses" of the property interest. Furthermore, there must also be a corresponding acquisition of a benefit by government.

In Steer Holdings Ltd. v. Manitoba, ${ }^{48}$ a change in land development regulations that prohibited the claimant from building a bridge to connect two parcels of land did not support a finding of de facto expropriation even though it significantly decreased the value of the land. The Manitoba Court of Appeal held that although the regulations restricted what the claimant could do with the property, there was "no corresponding benefit or acquisition by the Province of Manitoba." 49 It is interesting to note that the Court rejected the claimant's argument that the legislation benefited the province of Manitoba by enlarging a park system through linkage with a nature park. The failure of this argument likely has less to do with whether a park can be considered a benefit, and more to do with the fact that even with the regulation the land remained private and the claimant and its invitees still had exclusive use of the land (that is, not all reasonable uses had been removed).

In Mariner Real Estate, ${ }^{50}$ the Nova Scotia Court of Appeal held that a de facto expropriation is not demonstrated by a loss of economic value in a proprietary interest. In this case, claimants owned undeveloped shore properties that had been subsequently classified as beaches, and were unable to obtain compensation when they were denied permits to build single family dwellings on their properties. The claim for de facto expropriation failed because not all reasonable uses of the claimants' property interest had been removed. Specifically, the claimants had not applied for permits for other reasonable or traditional uses of lands, or explored the possibility of using environmentally appropriate development plans. ${ }^{51}$ The Court noted that previous cases finding compensable de facto expropriation (for example, Manitoba Fisheries, Tener, and Casamiro) involved governmental action that went beyond drastically limiting use or reducing the economic value of the owner's property. In those cases, rights were “completely negated," “meaningless,” or “absolutely prohibited."52 The Court confirmed that extensive land use regulation "has, almost without exception, been

(1992), 99 D.L.R. (4th) 61 (Man. C.A.) [Steer Holdings].

Ibid. at 67

Supra note 28.

Ibid. at 718-19. The Court emphasized that "where a regulatory regime is imposed on land, its actual application in the specific case must be examined,” not just its potential for interference with the owner's activities. In particular, regulatory takings cases in the U.S. require there to be "a final decision regarding the application of the challenged regulations to the property" (i.e., it is not the designation of lands as a beach which effects a de facto expropriation, but also the refusal of permission to develop the lands) [emphasis in original]. 
found not to constitute compensable expropriation.. ${ }^{, 53}$ Rather, regulation will be held to be a de facto expropriation only when "virtually all of the aggregated incidents of ownership have been taken away" ${ }^{34}$ and not when there has been a decrease in the value of the property interest. ${ }^{55}$ The Court did note, however, that while a decline in economic value does not necessarily equate to a de facto expropriation, it may be evidence of it. Where land use regulation has the effect of eliminating "virtually all the normal incidents of ownership, this will be reflected in the market value" of the property interest. ${ }^{56}$

In Mariner Real Estate, the Court also found that there had been no acquisition for the purposes of the Expropriation Act. ${ }^{57}$ Specifically, the Court held that there must be an acquisition of an actual interest in land and that the enhanced value of public land is not such an interest. ${ }^{58}$ This is a narrow interpretation of the type of benefit that can be acquired through government regulation and suggests that the nature of the benefit acquired by government must be the same as the proprietary interest that has effectively been confiscated. Not only is this seemingly at odds with Tener, it does not make practical sense because, by definition, a de facto expropriation will not necessarily involve a direct transfer of the confiscated interest. Rather, extensive regulation amounting to a de facto expropriation is more likely to give rise to benefits that differ in nature from the specific proprietary interest that has effectively been confiscated. As a result, adopting Mariner Real Estate's narrow interpretation of a beneficial interest would make it extremely difficult to establish a de facto expropriation claim since it requires claimants to demonstrate the acquisition of an interest by government that is equivalent in nature to the interest affected by the regulatory action.

Nilsson ${ }^{59}$ involved the Crown's adoption of a Restricted Development Area (RDA) to preserve lands for the purpose of building ring roads around Calgary and Edmonton. The claimant's land fell within the RDA and his application to develop a mobile home park on his property was refused. The Alberta Court of Queen's Bench reiterated the requirement for a "corresponding benefit in favour of the expropriating authority" before de facto expropriation is found. ${ }^{60}$ The Court indicated that such a benefit can be a general benefit to the public that promotes a specific public value or government project, as opposed to "the Crown making direct use of the owner's property in the same manner as the owner would have." ${ }^{61}$ This broader view of what constitutes a beneficial interest is consistent with the decision in Tener. The Court held that de facto expropriation had not been demonstrated because more was required than a mere restriction on use; the restriction must be of "sufficient severity to remove virtually all of the rights associated with the property holder's interest." ${ }^{\prime 62}$ In this case, the imposition of a development freeze and denial of a development

\footnotetext{
Ibid. at 713 .

Ibid. at 717 .

This approach was also adopted by the Superior Court of Quebec in Wallot c. Québec (Ville de), 2010 QCCS 1370, [2010] J.Q. no 2951 (QL). In this case, the requirement to place a band of vegetation on the edge of waterfront property to filter out contaminants decreased property values significantly, but did not constitute a de facto expropriation because some reasonable uses of the property remained. Supra note 28 at 727.

R.S.N.S. 1989, c. 156.

Supra note 28 at 732 .

Supra note 28, aff'd 2002 ABCA 283, 320 A.R. 88, leave to appeal to S.C.C. refused, [2003] 2 S.C.R. xi.

Ibid. at para. 35 .

Ibid. at paras. 54-55.

Ibid. at para. 48.
} 
permit for a mobile home park reduced the land's value, but the land use restrictions were not sufficient to constitute a de facto expropriation.

More recently, in Canadian Pacific Railway v. Vancouver (City of), the Supreme Court of Canada confirmed that the two requirements for a compensable de facto expropriation at common law are as follows: (1) "the acquisition of a beneficial interest in the property," or a benefit flowing from it; and (2) the "removal of all reasonable uses of the property." 63 Unfortunately, the Court did not provide extensive reasons when applying these principles in its decision. ${ }^{64}$

The facts involved a claimant railway company that owned a corridor of land which it no longer used for rail operations. The City of Vancouver refused to buy the land, but instead adopted the Arbutus Corridor Official Development Plan By-law, which designated the corridor as a public thoroughfare for transportation and greenways (for example, heritage walks, nature trails, and cyclist paths). ${ }^{65}$ The ODP By-law was essentially a statement of intention that did not commit the City Council to undertake any of the developments shown in the plan. However, development contrary to the ODP By-law was prohibited, effectively freezing the redevelopment potential of the corridor and preventing the claimant from putting the land to economic use.

The Court applied the principles regarding de facto expropriation narrowly and concluded that the necessary requirements were not met. The Court noted that "it is not necessary to establish a forced transfer of property" and confirmed that the "[a]cquisition of [a] beneficial interest related to the property suffices.”66 The Court found that the City had not acquired a beneficial interest related to the land and rejected the argument that it had acquired a "de facto park." The Court held that it was not a park because those who casually used the corridor are trespassers. The Court also stated that the City gained nothing more than "some assurance that the land will be used or developed in accordance with its vision." 67 This conclusion seems inconsistent with the facts of the case and with the broader view of what can constitute a benefit in Tener. Although the corridor was still private property, the ODP By-law effectively secured its future use as a public thoroughfare, an obvious benefit to the public. The Court appears to be implying that the nature of the benefit acquired must be the same as the property interest confiscated through regulation.

With respect to the second requirement for de facto expropriation, the Court determined that the bylaw did not remove all reasonable uses of the property because the claimant could

2006 SCC 5, [2006] 1 S.C.R. 227 at para. 30 [Canadian Pacific]. The articulation of the second branch of the test for de facto expropriation (that is, the removal of all reasonable uses) in this decision seems slightly different than Mariner Real Estate and Nilsson's articulation (that is, the removal of virtually all rights). However, it is unlikely that any substantive difference is intended since with both articulations of the test the focus is on the effect of the government regulation, which is whether the claimant is unable to exercise the rights at issue: see Mariner Real Estate, supra note 28 at 317. Canadian Pacific, ibid. at para. 37. The Court's cursory analysis may be due to the fact that the Vancouver Charter, S.B.C. 1953, c. 55, s. 569, had explicitly provided that the effects of the bylaw could not amount to a "taking," thus explicitly rendering the common law de facto expropriation remedy inapplicable.

65 City of Vancouver, Bylaw No. 8249, Arbutus Corridor Official Development Plan By-law (25 July 2000), s. 2.1 [ODP By-law].

$66 \quad$ Canadian Pacific, supra note 63 at para. 32.

$67 \quad$ Ibid. at para. 33. 
still use the land to operate and maintain a railway as it had in the past, lease the land for use in conformity with the bylaw, and develop public/private partnerships. ${ }^{68}$ The Court emphasized that "all reasonable uses" must not only be assessed in relation to the land's potential highest and best use, but must also have regard to the nature of the land and the range of reasonable uses to which it could be put. ${ }^{69}$

\section{GUIDANCE FROM CANADiAn CASE LAW}

Manitoba Fisheries and Rock Resources suggest that a wide range of property interests can be the subject of a de facto expropriation, including intangible (for example, goodwill) and chattel interests. The requirement for government acquisition of a beneficial interest has received inconsistent treatment. Cases like Mariner Real Estate, Canadian Pacific, and Steer Holdings take a restrictive approach and suggest that the nature of the benefit acquired must be similar, if not identical, to the proprietary interest subject to the regulation. Due to the nature of de facto expropriations, where no formal direct transfer of a proprietary interest occurs, the better view is the approach taken by the courts in Tener and Nilsson, which interpret a beneficial interest to include the removal of an encumbrance on Crown property, or a general benefit to the public that promotes a specific public value or government project. Some commentators have taken this even further by suggesting that the courts should do away with the requirement to acquire a benefit and focus solely on the scope of the property owner's loss in a determination for de facto expropriation. ${ }^{70}$

Canadian Pacific, Mariner Real Estate, and Nilsson confirm that the requirement for the removal of all reasonable uses of property means that a partial confiscation will not suffice. Furthermore, the removal of all reasonable uses of property is not the same as a decline in economic value, including a loss of virtually all economic value. Rather, Mariner Real Estate provides that a decrease in economic value may only be evidence that virtually all the normal incidents of ownership have been confiscated. Canadian Pacific, Casamiro, and Rock Resources also indicate that "reasonable uses" will be determined by factors such as the property interest's potential highest and best use, the range of reasonable uses to which the property interest has actually been put, and a consideration of the uses that could have been reasonably anticipated by the claimant when it acquired the property interest.

\section{B. THE U.K. EXPERIENCE}

The U.K. has an uncodified constitution and therefore has no constitutionally entrenched property rights. This means that, similar to Canada, expropriation and compensation for expropriation must be based in statute. The common law presumption in favour of compensation as articulated in De Keyser also applies. ${ }^{71}$ In general, the U.K. approach is consistent with the legal principles regarding de facto expropriation developed in Canada, but provides little direction regarding the application of these principles. ${ }^{72}$

Ibid. at para. 34 .

Ibid., citing Mariner Real Estate, supra note 28 at 717.

Brown, supra note 22 at 191-92.

Supra note 26.

Manitoba Fisheries, supra note 26 at 107-108 cites Ulster Transport Authority v. James Brown \& Sons, Ltd., [1953] N.I. 79, as an example of a de facto expropriation in the U.K., but the case was in the context of a furniture moving business. 
In the context of a development application that was refused due to incompatibility with residential zoning, the House of Lords held in Belfast (Corp.) v. O.D. Cars Ltd. that the restriction or denial of the right to use property in a particular way is not a "taking" of property. ${ }^{73}$ In $R$. (Trailer and Marina (Leven) Ltd.) v. Environment Secretary $(C A)^{74}$ the England and Wales Court of Appeal considered restrictions on the use of a canal that was designated as a site of special scientific interest. The Court acknowledged that what is not a formal expropriation may still amount to a de facto expropriation for the purposes of the property protections under art. 1 of the First Protocol to the Council of Europe's Convention for the Protection of Human Rights and Fundamental Freedoms. ${ }^{75}$ In such cases, the Court "must look behind the appearances and investigate the realities of the situation complained of." "76 In this case, the Court did not find that the legislation's provisions that controlled the use of property amounted to a "disguised appropriation.",77

In Adams v. Scottish Ministers, the Scottish Court of Session explained that the Court "must consider whether the situation complained of amounts to a de facto expropriation by depriving the [claimant] of all meaningful use of the property in question." ${ }^{\text {"7 }}$ This case involved a petition challenging the validity of legislation that prohibited fox hunting. The Court held that such legislation was not a de facto expropriation of the claimants' hounds. Rather, the legislation merely controlled the use of the hounds and the claimants were entitled to use the hounds for a variety of other sporting purposes. ${ }^{79}$ As a result, there was no de facto expropriation because the claimants were not deprived of all meaningful use of their hounds.

\section{THE U.S. EXPERIENCE}

The U.S. approach to de facto expropriation is grounded in its constitutional entrenchment of property rights and right to compensation for takings. Specifically, the Fifth Amendment to the U.S. Constitution (known as the "Takings Clause") provides that "[n]o person shall be ... deprived of life, liberty, or property, without due process of law; nor shall private property be taken for public use, without just compensation." ${ }^{80}$ Similarly, the Fourteenth Amendment (known as the "Due Process Clause") states that no state shall "deprive any person of life, liberty, or property, without due process of law." 81 These constitutional guarantees are "designed to bar Government from forcing [individuals] to bear public burdens which, in all fairness and justice, should be borne by the public as a whole." ${ }^{2}$ The U.S. Constitution does not prohibit the government from taking private property; rather, it explicitly makes compensation a condition of exercising that power. This means that, unlike Canada, once private property has been "taken for public use" there is an automatic right to compensation that does not have to be derived from individual pieces of legislation. This

(1959), [1960] 2 W.L.R. 148 at 154 (H.L. (N.I.)).

[2004] EWCA Civ 1580, [2005] 1 W.L.R. 1267 [Trailer and Marina].

4 November 1950, 213 U.N.T.S. 221, Eur. T.S. 5.

Sporrong and Lönnroth v. Sweden (1982), 5 E.H.R.R. 35 at para. 63, cited in Trailer and Marina, supra note 74 at para. 47.

Trailer and Marina, ibid. at para. 71.

[2004] SC 665 at para. 93 (Ct. Sess. Scot.).

Ibid. at para. 94 .

U.S. Const. amend. V.

U.S. Const. amend. XIV, § 1.

Armstrong v. United States, 364 U.S. 40 at 49 (1960). 
makes sense because, arguably, an unjust enrichment would occur when the public receives a benefit at someone's expense when no compensation is paid.

\title{
1. U.S. PRINCIPLES ON REGULATORY TAKINGS
}

In the U.S., the concept of de facto expropriation is typically referred to as a "regulatory taking" and was first introduced in the 1922 U.S. Supreme Court decision in Pennsylvania Coal Co. v. Mahon. ${ }^{83}$ This decision articulates the general rule that "while property may be regulated to a certain extent, if a regulation goes too far it will be recognized as a taking." 4 Specifically, the Court stated as follows:

\begin{abstract}
Government hardly could go on if to some extent values incident to property could not be diminished without paying for every such change in the general law. As long recognized some values are enjoyed under an implied limitation and must yield to the police power. But obviously the implied limitation must have its limits or the contract and due process clauses are gone. One fact for consideration in determining such limits is the extent of the diminution. When it reaches a certain magnitude, in most if not in all cases there must be an exercise of eminent domain and compensation to sustain the act. So the question depends upon the particular facts. $^{85}$
\end{abstract}

The Court warned that a strong public desire to improve the public condition is not enough to warrant circumventing the constitutional right to compensation. ${ }^{86}$ Pennsylvania Coal opened the door for regulatory taking claims, but left the question of exactly when regulation is considered to have gone "too far."

The seminal U.S. case on regulatory takings is the U.S. Supreme Court decision in Penn Central Transportation v. New York (City of). ${ }^{87}$ Penn Central confirmed that regulatory taking claims are approached as essentially “ad hoc, factual inquiries” and outlined certain factors that have particular significance when determining what constitutes a regulatory taking: (1) the "economic impact of the regulation on the claimant"; (2) "the extent to which the regulation has interfered with distinct investment-backed expectations"; and (3) the "character of the governmental action." ${ }^{88}$ When making this determination, the Court noted that the inquiry should not divide the parcel of property rights into discrete segments, but rather should focus on the parcel as a whole. ${ }^{89}$

The decision in Lingle v. Chevron U.S.A. confirmed that regulatory taking claims are governed by the Penn Central analysis, with the exception of two categories of regulatory action that generally will be deemed to be "per se takings": (1) where the government requires an owner to suffer a permanent physical invasion of property (that is, a physical taking); and (2) confiscatory regulations that prohibit all economically beneficial or

260 U.S. 393 (1922) [Pennsylvania Coal].

Ibid. at 415 .

Ibid. at 413 .

Ibid. at 416

438 U.S. 104 (1978) [Penn Central].

Ibid. at 124

Ibid. at 130-31. 
productive use of the land (that is, a "total regulatory taking"). ${ }^{90}$ If a claim falls into the category of a physical taking or total regulatory taking, it will be deemed a regulatory taking without needing to undergo the Penn Central analysis. The Court also explained that an exception to the "total regulatory taking" category exists when limitations on use merely duplicate existing restrictions in "background principles of the State's law of property and nuisance” that were already in place when the land was acquired by the claimant. ${ }^{91}$

In the U.S., a takings claim must also be "ripe.” This means that the government entity charged with implementing the regulations must have the opportunity to reach "a final decision regarding the application of the regulations to the property at issue." ${ }^{\text {"2 }}$ Until the property owner has followed reasonable and necessary steps to allow regulatory agencies to exercise their full discretion and come to a decision in considering the application to develop the property, "the extent of the restriction on property is not known and a regulatory taking has not yet been established." 93 This is because a court cannot determine whether a regulation has gone "too far" unless it knows how far the regulation goes. ${ }^{94}$

\section{TOTAL REgULATORY TAKINGS}

Due to its similarity to the Canadian requirement for the removal of "all reasonable uses" of the property interest, the U.S. approach to "total regulatory takings" warrants a closer look. U.S. Courts have interpreted "total" in the total regulatory takings category very literally, thus severely limiting the scenarios that could fall into this category. It is clear that economic value can also play a very prominent role in establishing a total regulatory taking.

The most well-known example of a total regulatory taking is found in Lucas$^{95}{ }^{95}$ where legislation barred the claimant from erecting any permanent habitable structures on two parcels of land near the South Carolina coast. The legislation was enacted two years after the claimant had acquired the land. The trial court held that the resulting prohibition rendered the claimant's parcels of land valueless. ${ }^{96}$ The U.S. Supreme Court confirmed that there can be a categorical total regulatory taking "where regulation denies all economically beneficial

544 U.S. 528 at 538 (2005) [Lingle]. See also Loretto v. Teleprompter Manhattan CATV Corp., 458 U.S. 419 (1982); Lucas v. South Carolina Coastal Council, 505 U.S. 1003 at 1015 (1992) [Lucas]. The Court also acknowledged that a regulatory takings claim may be analyzed in the special context of land use exactions where the government "demands that a landowner dedicate an easement allowing public access to [their] property as a condition of obtaining a development permit”: Lingle at 546. See also Dolan v. Tigard (City of), 512 U.S. 374 (1994); Nollan v. California Coastal Commission, 483 U.S. 825 (1987).

91 Lucas, ibid. at 1029. For example, in Stop the Beach Renourishment, Inc. v. Florida Department of Environmental Protection, 130 S. Ct. 2592 (2010), Florida sought to deposit additional sand along the coastline to curb erosion. The additional sand would become public land and the existing landowners of beachfront property argued that this would result in a taking of their riparian right to accretion. The U.S. Supreme Court held that this was not a taking because, due to background principles of state property law, a landowner's right to accretion was subordinate to the state's right to fill in its own seabed. See also James L. Huffman, "Background Principles and the Rule of Law: Fifteen Years After Lucas” (2008) 35 Ecology L.Q. 1. Williamson County Regional Planning Commission v. Hamilton Bank of Johnson City, 473 U.S. 172 at 186 (1985), cited in Palazzolo v. Rhode Island, 533 U.S. 606 at 618 (2001) [Palazzolo].

93 Palazzolo, ibid. at 620-21.

$94 \quad$ MacDonald, Sommer \& Frates v. Yolo (County of), 477 U.S. 340 at 348 (1986). This proposition was also cited in Mariner Real Estate, supra note 28 at 718.

95 Supra note 90.

$96 \quad$ Ibid. at 1007. 
or productive use of land." ${ }^{97}$ The above-mentioned exception to the total regulatory taking category did not apply because the government was unable to show that background principles of nuisance and property law would have prevented the erection of any habitable or productive improvements on the claimant's land. The Court therefore concluded that there had been a total regulatory taking requiring compensation. The Court also indicated in a footnote that this categorical rule would not apply if the diminution in property value were 95 percent instead of 100 percent. $^{98}$ This suggests that anything less than a complete elimination of value or total loss would not qualify as a total regulatory taking, and require a Penn Central analysis.

Palazzolo ${ }^{99}$ involved similar legislation that greatly limited the development of designated "coastal wetlands." The claimant's applications to develop land designated as "coastal wetlands” were rejected. The U.S. Supreme Court did not find this to constitute a total regulatory taking because the uplands portion of the property still retained $\$ 200,000$ in development value (about 6 percent of the expected property value absent the legislation), which meant that the property had not been left "economically idle" like it had been in Lucas. $^{100}$

In Tahoe-Sierra Preservation Council v. Tahoe Regional Planning Agency, ${ }^{101}$ the U.S. Supreme Court confirmed that temporary restrictions merely causing a diminution in property value are not total regulatory takings. Logically, a property interest could not be rendered valueless by a temporary prohibition on economic use because the property will recover value as soon as the prohibition is lifted. Accordingly, a 32-month moratorium on development for the purposes of formulating a comprehensive land use plan for the area was not considered a total regulatory taking because it was only a temporary restriction. ${ }^{102}$

\section{REgUlatory TAKINGS OF NATURAL RESOURCE INTERESTS}

U.S. jurisprudence on regulatory takings in the natural resource context deals primarily with property interests in coal. In Pennsylvania Coal, a coal company challenged the constitutionality of legislation that prohibited coal mining in a manner that would cause subsidence of any structure used as a human habitation. When the legislation was enacted, surface owners filed a complaint involving a deed that had expressly reserved the right of the coal company to remove coal without any liability to the surface owners. While Pennsylvania Coal predated Penn Central, the U.S. Supreme Court considered factors similar to those listed in Penn Central when reaching its conclusion that the legislation was not a valid exercise of police power. The Court noted that the legislation destroyed the claimant coal company's previously existing rights of property and contract and that this was not justified as a protection of personal safety or other public interest. Specifically, the case involved a

Ibid. at 1015.

Ibid. at 1019, n. 8.

Supra note 92.

Ibid. at 631.

535 U.S. 302 (2002).

Appolo Fuels v. United States, 381 F.3d 1338 at 1351 (Fed. Cir. 2004) [Appolo Fuels], affirmed that

"[d]elay in the regulatory process cannot give rise to takings liability unless the delay is extraordinary." If the delay is extraordinary, the question of partial regulatory takings liability is determined using the Penn Central factors. In Appolo Fuels an 18-month delay was found to be far short of extraordinary. 
single private house, and the legislation only benefited surface owners who had released their right to support in the deed. ${ }^{103}$ Essentially, there was a taking because regulation had gone "too far" and the legislation was held to be unconstitutional.

Subsequent regulatory taking claims for property interests in coal have been less successful. Typically, the affected property interest will still retain some value, which blocks a claim for a total regulatory taking. A claim for a partial regulatory taking under the Penn Central analysis is also usually unsuccessful because the substantial overall diminution in property value is outweighed by considering the reasonableness of investor-backed expectations and the existence of a sound public interest rationale for the government action.

For example, Keystone Bituminous Coal Association v. DeBenedictis ${ }^{104}$ involved legislation requiring 50 percent of the coal beneath public buildings, dwellings used for human habitation, and cemeteries to be kept in place to provide surface support. The U.S. Supreme Court applied the Penn Central analysis and concluded that there was no regulatory taking. The claimants failed to demonstrate a deprivation significant enough to satisfy the heavy burden placed on the party alleging a regulatory taking because they did not claim that the legislation had rendered their mining operations unprofitable. ${ }^{105}$ Less than 2 percent of their coal was required to be left in place due to the regulation and the remaining coal did not constitute a separate segment of property for takings law purposes. Furthermore, the value of the support estate (that is, the right of surface support) was merely a part of the entire bundle of rights possessed by the claimant as owner of the coal. Considering that only 75 percent of the claimant's coal could have been profitably mined in any event, there was also no evidence that reasonable investment-backed expectations had been materially affected by the legislation. ${ }^{106}$ The Court also noted that unlike Pennsylvania Coal, the legislation in Keystone did not serve private interests only, but rather was intended to protect a legitimate public interest in health, environment, and fiscal integrity of the area. ${ }^{107}$

The claimant in Rith Energy v. United States ${ }^{108}$ was also unsuccessful. The claimant owned two coal mining leases but its permit to conduct mining operations was suspended due to the potential for groundwater pollution through acid mine drainage. The Court held that this did not constitute a total regulatory taking because, although the regulatory action caused a substantial diminution in the value of the coal leases, the claimant was still able to make a profit from the coal extracted prior to the suspension of the permit. Furthermore, under existing background principles of nuisance (that is, an exception to total regulatory taking) the claimant had no right to mine in a way that was likely to produce acid mine drainage. The Court also found that there was no partial regulatory taking in accordance with a Penn Central analysis. The nature of the governmental action was a valid exercise of police power "directed at protecting the safety, health, and welfare of the communities surrounding the Rith mine site by preventing harmful runoff." ${ }^{109}$ The legislation at issue had also been in place eight years before the claimant had purchased the coal leases and the claimant could

\footnotetext{
103 Pennsylvania Coal, supra note 83 at 413-14.

104480 U.S. 470 (1987) [Keystone].

105 Ibid. at 493 .

$106 \quad$ Ibid. at 499

$107 \quad$ Ibid. at 471

108247 F.3d 1355 (Fed. Cir. 2001) [Rith Energy], rehearing denied, 270 F.3d 1347 (Fed. Cir. 2001).
}

$109 \quad$ Ibid. at 1352. 
not reasonably have expected that it would be free from regulatory oversight given the potential for acid mine drainage. Rith Energy clarifies that the regulatory regime in place at the time the claimant acquires the property at issue informs the reasonableness of investmentbacked expectations. However, this does not mean that when governmental action regulates the use of property, a person who purchases property after the date of the regulation may never challenge the regulation under the Takings Clause. ${ }^{110}$

The uphill battle to establish a regulatory taking is further illustrated in Appolo Fuels. ${ }^{111}$ The relevant legislation provided for a lands unsuitable for mining (LUM) petition process that enabled the relevant state authority to designate an area unsuitable for surface coal mining for reasons such as the reduction of water supply productivity. The claimant owned several leases that fell within a LUM petition area that was designated as unsuitable for all surface coal mining operations. The U.S. Court of Appeals, Federal Circuit, held that there was no total regulatory taking because there was only a 92 percent loss of value of one lease and a 78 percent loss of another lease. When applying the Penn Central analysis, the Court concluded that the claimant's lack of reasonable investment-backed expectations and the nature of the government action outweighed the claimant's severe economic injury. ${ }^{112}$ Specifically, the government action was designed to protect health and safety. With respect to what constitutes reasonable investment-backed expectations, the Court in Appolo Fuels outlined three relevant factors to consider: (1) "whether the claimant operated in a 'highly regulated industry"”; (2) whether the claimant "was aware of the problem that spawned the regulation at the time it purchased the allegedly taken property"; and (3) whether the claimant “could have 'reasonably anticipated' the possibility of such regulation in light of the 'regulatory environment' at the time of purchase."113 In this case, the claimant lacked reasonable investment-backed expectations because the coal mining business was a highly regulated industry; the claimant should have been aware that surface mining was a potentially environmentally hazardous activity; and the claimant could have reasonably anticipated the possibility of a LUM decision prohibiting the mining of part or all of its leases. ${ }^{114}$ This is particularly so given that the legislation was enacted long before the claimant's acquisition of the mining leases.

\section{GUIDANCE From U.S. CASE LAW}

While the overall legal test for regulatory takings in the U.S. is different from Canada, the situation in the U.S. is similar to Canada in that it is difficult to successfully establish a regulatory takings claim. The U.S. approach focuses on the severity of the burden that government imposes upon private property rights, ${ }^{115}$ rather than on whether there has been a government acquisition of a beneficial interest in, or flowing from, the property. Nevertheless, U.S. jurisprudence is still useful for revealing considerations that may inform a principled determination of de facto expropriation in Canada.

This is consistent with the Court's finding in Casamiro that mineral claims could still be subjected to de facto expropriation despite being granted after the provincial park designation.

Supra note 102.

Ibid. at 1351.

Ibid. at 1349, citing Commonwealth Edison v. United States, 271 F.3d 1327 at 1348 (Fed. Cir. 2001).

Appolo Fuels, ibid.

Lingle, supra note 90 at 542-44. 
With respect to the Canadian requirement for the removal of all reasonable uses, U.S. case law emphasizes the need to assess the proprietary interest as a whole parcel. In fact, the success of the claimants in Tener, Casamiro, Rock Resources, and Pennsylvania Coal may be attributable to the smaller bundle of rights held under their mineral claims relative to the bundle of rights one would possess if they had title; the only way the claimants could enjoy their specific rights was through the exploitation of the minerals, whereas with title there are a number of potential reasonable uses that a parcel of land can have.

In the U.S., a complete loss of economic value automatically equates to a regulatory taking. This differs from the Canadian approach, which requires both a government acquisition of a beneficial interest and the "removal of all reasonable uses" of a property interest. The potential advantage of using the complete loss of economic value as a benchmark is that it may be established in a more objective manner, and therefore creates greater certainty in terms of entitlement to compensation. Additionally, consideration of reasonable investor-backed expectations and the background principles of property and nuisance law can inform the "reasonable uses" that can be confiscated. Indeed, if a claimant could have reasonably anticipated a potential regulatory restriction, or never acquired a particular right in the first place due to existing property and nuisance laws, this limits the range of "reasonable uses" considered in the de facto expropriation analysis.

Although older case law appears more willing to find a de facto expropriation, the U.S. approach to regulatory takings has evolved so that unless a claimant has been deprived of 100 percent of the economic or productive use of the property interest, or suffered a physical taking, the claimant must depend on a partial regulatory taking under the Penn Central analysis. A partial regulatory taking is difficult to establish since substantial loss of economic value is often outweighed by the lack of reasonable investment-backed expectations or the character of the governmental action.

\section{The AUSTRALIAN EXPERIENCE}

While the U.S. Constitution limits government's expropriating powers by protecting rights to property and compensation, the Commonwealth of Australia Constitution Act ensures that government has the authority to expropriate. ${ }^{116}$ Specifically, s. 51(xxxi) of the Australian Constitution Act empowers the Commonwealth Parliament to enact laws for "the acquisition of property on just terms from any State or person for any purpose in respect of which the Parliament has power to make laws.” The right to compensation for expropriation from the Commonwealth flows from the requirement for "just terms."

\section{ACQUISITION OF PROPERTY}

Similar to Canada, Australia's approach to de facto expropriations focuses on whether there has been an acquisition by the government. Due to the language of s. 51(xxxi) of the Australian Constitution Act, the emphasis is on the acquisition of "property" rather than a "benefit," but there are indications that "property" includes identifiable benefits or advantages relating to the ownership or use of property. 
The need for an acquisition was discussed in Commonwealth $v$. Tasmania,${ }^{117}$ a case where the Government of Tasmania planned to construct a dam in a wilderness area that the Commonwealth of Australia wished to preserve for environmental and cultural reasons. Legislation was enacted by the Commonwealth to prohibit the construction of a dam without the consent of a Commonwealth Minister. Since the Commonwealth did not support the construction of the dam, this prohibition effectively sterilized the property's potential use. ${ }^{118}$ The majority of the High Court held that this did not constitute a s. 51(xxxi) acquisition. Justice Mason noted that the application of s. 51(xxxi) required an acquisition of a property interest:

To bring the Constitutional provision into play it is not enough that legislation adversely affects or terminates a pre-existing right that an owner enjoys in relation to his property; there must be an acquisition whereby the Commonwealth or another acquires an interest in property, however slight or insubstantial it may be. ${ }^{119}$

In this case, the power of the Minister to refuse consent was characterized as a power of veto over any development of the property. The Court held that this power was not a proprietary right and did not amount to "a vesting of possession in the Commonwealth."120 Similar to Mariner Real Estate, Canadian Pacific, and Steer Holdings, this is a more narrow view of the type of interest that can be acquired through regulation. However, given that the Commonwealth legislation was not an absolute prohibition, and consent could be provided by the Minister (and possibly by a future Minister), that may provide a rationale for why the Court held that a proprietary right had not vested in the Commonwealth.

In Newcrest Mining (W.A.) Ltd. v. Commonwealth, ${ }^{121}$ the High Court adopted a broader interpretation of what constitutes an acquisition in a manner consistent with the approach in Tener and Nilsson. Newcrest Mining involved facts similar to those in Tener: the claimant held mining leases in an area that was later declared to be part of Kakadu National Park under two proclamations. Legislation applicable to national parks explicitly stated that "[n]o operations for the recovery of minerals shall be carried on in Kakadu National Park,” and that the Commonwealth was not liable to pay compensation to any person by reason of the legislation's enactment. ${ }^{122}$

The majority of the High Court found that the proclamations were invalid for failure to provide just terms for acquisitions of property from the claimant. The judgment did not turn on the question of whether the proclamations had the effect of the government acquiring property under s. 51(xxxi) of the Australian Constitution Act. Instead, the focus was on whether s. 51(xxxi) was applicable to the proclamations at all since the Commonwealth argued that it had acted under a different section of the Constitution that was not qualified by the requirement of "just terms." Nevertheless, in one of the majority opinions, Gummow J. expressed the view that the identifiable benefit or advantage relating to the ownership or use of property acquired did not need to correspond precisely to what was taken. ${ }^{123}$ Justice

$\begin{array}{ll}117 & \text { [1983] HCA 21, } 158 \text { C.L.R. } 1 . \\ 118 & \text { Ibid. at para. 70. } \\ 119 & \text { Ibid. at para. 68. } \\ 120 & \text { Ibid. at para. 70. } \\ 121 & \text { [1997] HCA 38, } 190 \text { C.L.R. } 513 \text { [Newcrest Mining]. } \\ 122 & \text { Ibid. at 530. } \\ 123 & \text { Ibid. at 634. }\end{array}$


Gummow found that there was an effective sterilization of the claimant's property rights. Furthermore, the Director and Commonwealth acquired "identifiable and measurable advantages" because the land was freed from the rights of the claimant to occupy and conduct mining operations, and the Commonwealth acquired minerals freed from the rights of the claimant to mine them. ${ }^{124}$

Commonwealth v. WMC Resources Ltd. ${ }^{125}$ also signals acceptance of the view that an acquisition occurs with the removal of a liability. Chief Justice Brennan noted that "[i]f statutory rights were conferred on A and a reciprocal liability were imposed on B and the rights were proprietary in nature, a law extinguishing A's rights could effect an acquisition of property by B." ${ }^{\prime 26}$ This view supports the comments of Wilson J. in Tener, who considered the removal of an encumbrance to be an acquisition that benefited the Crown. While WMC Resources involved the partial extinguishment of offshore oil exploration permits, this did not result in an acquisition of property by the Commonwealth. The permits did not impose a reciprocal liability on the Commonwealth because it did not have a proprietary interest in the continental shelf. ${ }^{127}$

Failing to employ a principled approach when determining whether there has been an acquisition can lead to diverging conclusions on what can be the subject of an acquisition. This is apparent in the High Court of Australia decision in ICM Agriculture Pty Ltd v. The Commonwealth. ${ }^{128}$ In this case, legislation had the effect of replacing groundwater bore licences with aquifer access licences and resulted in a decrease in groundwater entitlements ranging from 66 to 70 percent for the claimants. Chief Justice French, with Gummow and Crennan JJ. concurring, seemed heavily influenced by the "insubstantial character" of the bore licences, but ultimately grounded their opinion on the fact that groundwater could not be the subject of private rights because "the State always had the power to limit the volume of water to be taken from that [natural] resource." ${ }^{129}$ Due to this, there could be no acquisition under s. 51(xxxi) of the Australian Constitution Act.

Justices Hayne, Kiefel, and Bell also concluded that there had been no acquisition in this case. They considered the "replaceable and fugitive nature of groundwater," that the licences were "a creature of statute and inherently fragile," that groundwater is not thought to be a subject of property, and that the state was vested with statutory rights to control access to a public resource. ${ }^{130}$ They concluded that the state gained no identifiable or measurable advantage from the new licencing system. More specifically, the claimant's rights under their bore licences did not "return" to the state upon cancellation of the licences. ${ }^{131}$ The state itself did not gain a larger or different right to extract or permit others to extract water from the system.

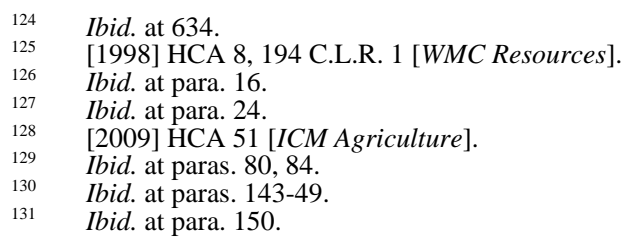


The dissenting opinion of Heydon J. provides a different view and concluded that the extinguishment of the bore licences was an acquisition of property based on the following rationale: (1) to the extent which the claimant's rights were reduced, they were placed in the control of the government; (2) the extinguishment of the claimant's bore licence rights relieved the government of liabilities; and (3) there was a contingent increase in capacity for the government to take water for its own use or grant more rights to water. ${ }^{132}$ While this dissent is more consistent with the views expressed in Newcrest Mining and WMC Resources, it appears that the decision of the majority was heavily influenced by the public nature of the water resource.

\section{GUIDANCE From Australian CASE LAW}

Similar to Canada, Australian jurisprudence reveals an unpredictable interpretation of what constitutes an acquisition by the government. The range of views in ICM Agriculture highlights this uncertainty. The broader approach suggested by Gummow J. in Newcrest Mining, Brennan C.J. in WMC Resources, and Heydon J. in ICM Agriculture is more reasonable in its finding that the removal of a liability on a proprietary interest constitutes an acquisition given the benefit that accrues to the government.

\section{COMPENSATION FOR THE DE FACTO EXPROPRIATION of NATURAL RESOURCE AsSETS}

Once the requirements for a de facto expropriation are met, two more obstacles to obtaining compensation remain: (1) express statutory abrogation of compensation; and (2) determining the quantum of compensation.

\section{A. ENTITLEMENT TO COMPENSATION}

As mentioned above, property rights in Canada are not constitutionally protected and are vulnerable to legislative diminution. As De Keyser explained, the presumption in favour of compensation does not operate where statutes expressly provide otherwise. For example, in Canadian Pacific the Court found that any common law entitlement to compensation had been negated by the Vancouver Charter, which expressly stated that the City was not obliged to compensate for adverse effects to land caused by an official development plan. ${ }^{133}$ Similarly, in Durham Holdings Pty. Ltd. v. New South Wales, the High Court of Australia found that the presumption against the acquisition of property without compensation was rebutted by a statutory provision that clearly authorized a cap on the amount of compensation to be paid for coal vested in the Crown. ${ }^{134}$

The strength of the common law presumption in favour of compensation should also not be underestimated. If legislation is silent on compensation, this will not suffice to immunize the Crown from the need to pay compensation. For example, in Rock Resources the

$132 \quad$ Ibid. at paras. 231-35.

$133 \quad$ Supra note 63 at para. 37; Vancouver Charter, supra note 64, s. 569.

134 [2001] HCA 7, 205 C.L.R. 399 at para. 6. Note that protection under s. 51(xxxi) of the Australian Constitution Act, supra note 116, did not apply in this case because the facts involved a state acquisition law, as opposed to a Commonwealth acquisition law. 
regulatory regime had been amended so that, unlike Tener and Casamiro, the mineral claims were no longer considered to be interests in land, but deemed to be chattel interests. ${ }^{135}$ The British Columbia Park Act contained a compensation mechanism for land, ${ }^{136}$ but was silent with respect to mineral claims. The Court determined that this silence was not evidence of a clear legislative intent sufficient to rebut the presumption that compensation would be paid.

Essentially, the Canadian state may expropriate "with impunity so long as it does so transparently." 137 The government must balance the political consequences of expropriating property interests without compensation against the need to introduce social and environmentally beneficial legislation unimpeded by expectations of compensation. Natural resource developers must recognize that there is this risk of the government passing legislation that will expressly absolve the government from the need to pay compensation and immunize it from liability for a traditional or de facto expropriation.

\section{B. Determining the Amount of Compensation}

The heterogeneous nature of natural resource interests poses a serious challenge for determining the amount of compensation that should be paid for a de facto expropriation of natural resource interests. The value of a natural resource interest depends heavily on the information available on the resource. The quantum of compensation for natural resource interests is usually contentious, and its determination is more of an art than a science. For example, consider the following points relevant to determining the value of a natural resource interest:

- The total value of an interest, including "potential output and profit, the market rate for the property interest (or in situ price of resource), the quantitative level of investment, or some combination of the above."

- Whether the de facto expropriation "entirely abrogated the interests or simply diminished them by some percentage.”

- “[I]f actual production has not started and there remain regulatory or environmental compliances to secure,” the likelihood of being allowed into production. ${ }^{138}$

Interestingly, some commentators suggest that compensation for natural resource interests should be set at zero, arguing that they are public resources owned by the government and, accordingly, the government has the right to allocate their use. ${ }^{139}$ This argument ignores the "contract" that the government enters into with the party who acquires the natural resource interest. Others submit that compensation may be unnecessary because developers should treat the possibility of expropriation as a market risk, ${ }^{140}$ but this position ignores the fact that

Supra note 45 at para. 63.

R.S.B.C. 1979, c. 309, s. 11(c).

Brown, supra note 22 at 183.

Patrick Hawkins-Bowman, "Government Withdrawals of Mining Interests” (1997) 2 Great Plains Nat. Resources J. 56 at 65.

Ibid. at 64-65. This view is consistent with the position taken by majority of the High Court in ICM Agriculture, supra note 128.

Hawkins-Bowman, ibid. at 65. 
expropriation deprives property owners of something of value. If the government determines that compensation is not appropriate in certain circumstances, it has the option to expressly bar the right to compensation in legislation in a clear and transparent manner, and suffer the potential political and economic fallout accordingly.

\section{PRINCIPLES For ASSESSING COMPENSATION}

A good starting place for determining compensation is to review the applicable regulatory regime or expropriation legislation for guidance. For example, the Alberta Oil and Gas Conservation Act authorizes the Alberta Energy Resources Conservation Board (ERCB) to establish schemes to provide compensation for persons who suffer a loss by reason of orders made pursuant to the Act. ${ }^{141}$ Such a compensation scheme may specify the circumstances under which a party is entitled to receive compensation under the scheme, matters for which compensation is payable, and the method by which the amount of any compensation is to be ascertained. $^{142}$

There will be occasions where the applicable legislation does not set out the details of a compensation scheme, ${ }^{143}$ or where legislation is silent on the right to compensation. In the absence of statutory criteria, the common law "value to the owner" standard forms the basis of compensation in Canada. ${ }^{144}$ Under this standard, the displaced owner should be left as closely as possible to the same position financially as they were prior to the confiscation. ${ }^{145}$ The question has been framed by the Supreme Court of Canada as what "a prudent man, at that moment, [would] pay for the property rather than be ejected from it."146 The common law value to the owner standard is similar to the standard set out in various expropriation statutes. Indeed, in Adroit Resources v. British Columbia the British Columbia Supreme Court held that since the value to the owner standard essentially comports with the British Columbia Expropriation Act, guidance can be taken from its provisions even where the Act does not apply. ${ }^{147}$

While market value is not definitive, it forms the primary basis for determining compensation. The definition of "market value" in the federal and provincial expropriation statutes are very similar. The federal Expropriation Act defines market value as "the amount that would have been paid for the interest if, at the time of its taking, it had been sold in the open market by a willing seller to a willing buyer." ${ }^{148}$ Market value will often be based on

R.S.A. 2000, c. O-6, s. 99(1).

Ibid., s. 99(8). For example, a compensation scheme was put in place for persons affected by the Alberta Energy and Utilities Board (predecessor to the ERCB) Order dated 3 April 2000 concerning the issue of gas over bitumen and issued in accordance with Gulf Canada Resources Limited: Request for the Shut-in of Associated Gas - Surmont Area, EUB Decision 2000-22 (30 March 2000), ordering the shutin of gas production from 146 wells. All ERCB decisions can be found online: ERCB $<$ http://www.ercb.ca/portal/server.pt? $>$.

For example, s. 64 of the Species at Risk Act, S.C. 2002, c. 29 [SARA], authorizes the Minister of the Environment to "provide fair and reasonable compensation to any person for losses suffered" as a result of prohibitions relating to critical habitat for listed species and habitat identified in an emergency order. Regulations outlining the procedures for claiming compensation and the amount of compensation for loss have not yet been enacted.

Todd, supra note 23 at 109-11.

Irving Oil Co. Ltd. v. R., [1946] S.C.R. 551 at 556.

Diggon-Hibben Ltd. v. R., [1949] S.C.R. 712 at 715.

2009 BCSC 841, 96 B.C.L.R. (4th) 131 at para. 40 [Adroit Resources].

Supra note 24, s. 26(2). 
the highest and best use of the land. ${ }^{149}$ In addition to market value, other considerations relevant to compensation include disturbance damages, special value, severance damage and injurious affection, mitigation and abandonment, and interest and costs. ${ }^{150}$ At common law, "the burden of proof of market value rests on the owner of the expropriated property," but matters before expropriation compensation tribunals are "more in the nature of an investigation than a trial” so the onus rests on neither party. ${ }^{151}$ Instead, the duty is upon the tribunal to determine what market value is. The onus of making out a claim for disturbance damages lies on the claimant. ${ }^{152}$

Market value can be estimated through different appraisal methods. Courts and tribunals prefer the "direct sales comparison approach,” which involves making a direct comparison "between the subject property and other statistical information, particularly the sale prices of comparable properties on the open market." ${ }^{\text {"153 }}$ The direct sales comparison approach may be problematic in the context of natural resource interests that lack a transparent and open market (for example, exploratory mineral claims) and lack of true comparables. Due to this, alternative appraisal methods that are more complicated or subjective may need to be utilized.

In The Law of Expropriation and Compensation in Canada, Eric Todd provides a succinct explanation of two other appraisal methods: (1) the income (discounted cash flow) approach; and (2) the cost (appraised value) approach. ${ }^{154}$ The income approach involves a comparison of income derived from the subject property with "income derived from comparable properties or other types of investment." ${ }^{, 155}$ The income stream from the subject property is then capitalized at a rate derived from an analysis of the market and this is deemed to be the capital value of the subject property. The cost approach involves an estimate of "the current cost of reproducing the existing improvements on the subject property or the cost of replacing the improvements with those of equal functional utility."156 The estimated market value of the land determined by one or both of the direct sales comparison or income approach is then added on top.

\section{GUIDANCE FROM CASE LAW}

The appropriate appraisal method is contingent on the facts and information available in each case. In Casamiro 1993, the claimant argued that it was entitled to more than \$28 million in compensation for their Crown-granted mineral claims, while the province indicated that market value of the claims ranged from $\$ 10,000$ to $\$ 50,000 .{ }^{157}$ The British Columbia Expropriation Compensation Board (BCECB) noted that there was a need for extensive exploration on the subject property and that its reserves were all subjective. The highest and

See e.g. ibid., s. 26(3); Alberta Expropriation Act, supra note 24, s. 43; British Columbia Expropriation Act, supra note 24, s. 31.

Todd, supra note 23 at 128-30.

Casamiro Resource v. British Columbia (1993), 50 L.C.R. 99 at 141, 143 (BCECB) [Casamiro 1993], aff'd 2000 BCCA 407, 76 B.C.L.R. (3d) 303.

Todd, supra note 23 at 322.

Ibid. at 178, 181.

Ibid. at 178 .

Ibid.

Ibid.

Supra note 151 at 112-13. 
best use of the subject property was for "the exploration and development of a mineral resource, the potential of which [was] unknown."158 The BCECB held that the cost to replace the lost resource, not shown to be a scarce resource whose scarcity affects the market value of the land (for example, limestone or gold), is the cost of buying an equivalent area of land with that resource in the ground. ${ }^{159}$ In other words, "what would [a] buyer have paid for the right to risk development money in an unsuccessful attempt to bring the mine into production or alternatively, to bring the mine into successful operation and yield a return on an investment of \$10 to \$20 million?" 160 The BCECB found that the adjusted income approach in this case was too speculative and did not give a reliable indication of market value. The BCECB also rejected market capitalizations of shares in gold mining companies sold on Canadian stock exchanges as being comparable because there were "too many extraneous factors influencing the price of shares."161 Instead, the BCECB based market value on the price paid for a controlling block of shares in the claimant company and required $\$ 375,000$ plus interest to be paid for compensation. ${ }^{162}$

Compensation for the mineral claims confiscated in Rock Resources was evaluated by the British Columbia Supreme Court in Adroit Resources. The claimant estimated its compensation claim to be over $\$ 7.8$ million plus interest. The Court accepted that "the highest and best use of the claims at issue [was] as an exploration property." 163 The Court also recognized that the valuation of a potential mineral property "is highly speculative" and that "methods ... for valuation are somewhat subjective."164 The Court found the income approach unreliable because it seemed to be supported by nothing more than optimistic speculation. Instead, the Court placed the greatest weight on the cost approach, as well as some consideration of the direct sales comparison approach, and estimated the market value of the mineral claims to be $\$ 300,000 .{ }^{165}$ With respect to disturbance damages, the Court also awarded compensation for exploration costs and goodwill. The Court ordered that a total of $\$ 603,633$ plus interest be paid as compensation for the expropriated mineral claims. ${ }^{166}$

Morriss v. British Columbia ${ }^{167}$ also involved an evaluation of mineral claims that had little or no exploration work done on them. The claimant's expert assigned a value of $\$ 9$ million to the claims while the province's expert assigned a value of $\$ 40,000$ to the claims. Both experts made reference to the cost approach and direct sales comparison approach. The British Columbia Supreme Court did not find the direct sales comparison approach to be helpful due to the lack of true comparables. Differences in property size, stage of development and exploration, access, and closeness to proven resource rich areas left only one somewhat comparable property. ${ }^{168}$ The Court concluded that due to the early stages of

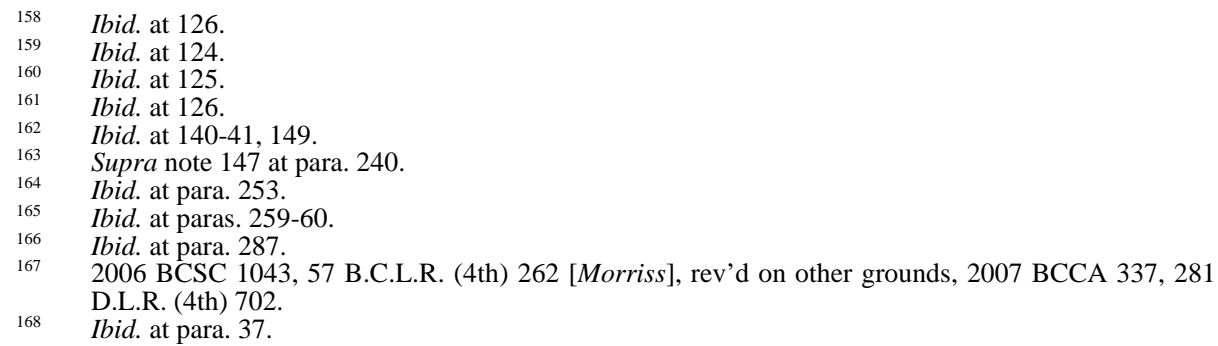


exploration, limited work done on the property, and lack of interest shown in the property in the past, the mineral claims should be valued at $\$ 125,000 .{ }^{169}$

\section{SUMMARY OF COMPENSATION PRINCIPLES}

Determining the amount of compensation for a natural resource interest depends on the facts. Legally, compensation under the common law or expropriation statutes is based on the "value to the owner" standard but, practically, this leaves a lot of room for differing interpretations. Where there are adequate numbers of true comparables and supporting statistical information, courts and tribunals prefer the direct sales comparison approach as an estimate of market value. This approach may be suitable for oil and gas leases given that their net present value can generally be estimated. Where there is a lack of true comparables, the cost approach can be used as an alternative. Adroit and Morriss illustrate the difficulties in utilizing an income approach, as it can be seen as being too speculative.

A natural resource interest may have the potential for great value, but there must be solid supporting evidence before this will be reflected in the compensation granted. Casamiro 1993, Adroit Resources, and Morriss indicate that where little exploratory work has been done to delineate the resource and the extent of the natural resource is unknown, courts and tribunals tend to award significantly less than what is claimed. This makes logical sense because greater uncertainty increases the risk associated with the interest, which should correspondingly reduce the market value of the proprietary interest. The inverse must also be true: where geological data or past production records can demonstrate greater certainty, the decreased risk associated with the nature of the resource should increase the market value of the natural resource interest. For example, compensation awards for established oil sands or shallow gas reserves should be higher than for more speculative interests that are in the exploratory stages of development.

\section{A Principled Approach to Establish COMPENSABLE DE FACTO EXPROPRIATIONS}

There are a number of regulatory regimes in Canada that have the potential to cause a de facto expropriation of natural resource interests. For example, the federal SARA prohibits the destruction of "critical habitat" for specified species at risk. ${ }^{170}$ SARA defines "critical habitat" to mean "the habitat that is necessary for the survival or recovery of a listed wildlife species and that is identified as the species' critical habitat in the recovery strategy or in an action plan for the species." 171 Unfortunately, for almost all listed wildlife species, the federal government has not fulfilled its obligation under SARA to finalize the identification of critical habitat. ${ }^{172}$ This regulatory gap can delay the development of a natural resource project (potentially indefinitely) because, if critical habitat is not identified, regulators may believe that species at risk cannot be adequately protected in proposed development areas. This issue

$169 \quad$ Ibid. at para. 110.

$170 \quad$ Supra note 143 , ss. 58, 61.

171 Ibid., s. 2(1).

172 The federal government's delay in designating critical habitat in recovery strategies has also become the subject of litigation: see e.g. Alberta Wilderness Association v. Canada (Minister of Environment), 2009 FC 710, 349 F.T.R. 63; Environmental Defence Canada v. Canada (Minister of Fisheries and Oceans), 2009 FC 131, [2009] F.C.J. No. 182 (QL). 
arose in the context of EnCana Corporation's Shallow Gas Infill Development Project at Canadian Forces Base Suffield ${ }^{173}$ and for the Mackenzie Gas Project, ${ }^{174}$ both of which underwent a rigorous environmental assessment and hearing before joint federal-provincial environmental assessment review panels.

$S A R A$ raises the question of whether government inaction should entitle a developer to compensation. Arguably, if a developer has proven reserves that are producible and marketable, and government regulation (or the failure of government to fulfill a legislated regulatory mandate) prevents the realization of those assets, this should be considered a compensable loss. The counter-argument, of course, is that the natural resource is not going anywhere, and it is just a matter of time before the rights holder can exercise those rights. What this counter-argument ignores is the potential opportunity loss associated with the government inaction-induced delay, and the investment decisions that would have been made on the presumption that government will fulfill its mandate in accordance with its own legislation.

Another situation presents itself under the recently enacted Alberta Land Stewardship $A c t,{ }^{175}$ where binding regional land use plans intended to integrate economic, environmental, and social factors are currently being developed. These regional land use plans will set thresholds and targets to address cumulative effects. In the context of ALSA, concerns about de facto expropriation arise due to the potential for these thresholds and targets to preclude the development of a company's natural resource assets. At present this is a serious unknown that has been the cause of concern for many natural resource development industry players. This is especially so given that the regional land use plans are binding on the Crown, local government bodies, decision-makers (including regulatory and permitting authorities), and the public. ${ }^{176}$

A further potential issue is that ALSA expressly limits the right to compensation for expropriation due to a loss arising from a "conservation directive," 177 and any other compensation must be sought under the compensation provisions provided under other provincial enactments. ${ }^{178}$ Given the potential for the de facto expropriation of natural resource interests over large tracts of land under $A L S A$ 's regional land use plans, it is unclear how other statutes will work in conjunction with $A L S A$ with respect to compensation, or

Report of the Joint Review Panel: EnCana Shallow Gas Infill Development Project - Canadian Forces Base Suffield National Wildlife Area, Alberta, EUB Decision 2009-008 (27 January 2009) at vi.

Canadian Environmental Assessment Agency, Foundation for a Sustainable Northern Future: Report of the Joint Review Panel for the Mackenzie Gas Project (December 2009), online: Mackenzie Valley Review Board <http://www.reviewboard.ca/upload/project_document/1263228660_JRP_Report_of_ Environmental_Review_Executive_Volume_I.pdf $>$.

S.A. 2009, c. A-26.8 [A $\bar{L} S A]$.

Ibid., s. 15(1).

"Conservation directives" involve expressly setting aside specific parcels of land under regional land use plans to "protect, conserve, manage and enhance environmental, natural scenic, esthetic or agricultural values”: ibid., s. 37.

Ibid., s. 19. Examples of other provincial enactments providing for compensation include the Alberta Expropriation Act, supra note 24 and the Oil Sands Conservation Act, R.S.A. 2000, c. O-7, s.18(8). It is interesting to note that certain interests (for example, a disposition, unit agreement, or contract) under the Mines and Minerals Act, R.S.A. 2000, c. M-17 are specifically excluded from being eligible for compensation under ALSA due to a conservation directive. See also Alan Harvie \& Trent Mercier, "The Alberta Land Stewardship Act and its Impact on Alberta's Oil and Gas Industry” (2010) 48 Alta. L. Rev. 295. 
whether other provincial enactments will be able to effectively manage the potential largescale de facto expropriation issue. For example, the issue may arise where a number of oil sands leases held by numerous developers are rendered effectively useless due to regulation under $A L S A$. The question then is whether holders of such oil sands leases have a right to be compensated for this loss and, if so, whether the existing provisions under provincial enactments can manage the potential of multiple, large-scale compensation claims.

Recent amendments to the Ontario Mining $A c t^{179}$ prohibit new mine openings in Ontario’s Far North if their locations are inconsistent with land use designated for those areas, or if there are no approved community based land use plans (CBLUPs) in place as developed by First Nations working jointly with the Ministry of Natural Resources. If enacted, Bill 191, ${ }^{180}$ the Far North Act, 2010 would also prohibit a number of activities, including opening a mine and engaging in oil and gas exploration or production on any public lands in Ontario's Far North where a CBLUP is not in place or that have been designated as a protected area. Under the Far North of Ontario Land Use Planning Initiative, it is expected that at least 225,000 $\mathrm{km}^{2}$ of Ontario's Far North will be designated as protected areas, ${ }^{181}$ thus rendering these areas unavailable to mining and to oil and gas exploration or production. As companies await the development of CBLUPs, the resulting delays may impact the value of their natural resource interests. Once CBLUPs are developed, their restrictions or designation of protected areas may also have the potential to effectively sterilize a company’s ability to develop its natural resource assets in Ontario’s Far North.

SARA, ALSA, the Ontario Mining Act, and the Far North Act, 2010 are some examples of how government regulation can severely restrict the exercise of natural resource interests. The introduction to this article posed the question of whether resource developers can and should be compensated when regulation of this nature effectively prevents them from developing their assets. Arguably, the answer ought to be “yes” when a party's property right, which they had a reasonable expectation of exercising, is confiscated. A principled application of the legal principles for de facto expropriation should support credible compensation claims based on the sterilization of natural resource interests due to government regulation. Moreover, from a policy perspective, compensation is also appropriate to ensure that informed decisions are made and actual costs are accounted for, particularly since the regulation is done for the public benefit.

When regulation by government prevents a resource developer from developing its assets, the following principled approach is recommended for determining whether there is a compensable de facto expropriation:

\section{(1) A property interest involves a "bundle of rights."}

There should be a presumption that owners of property interests are entitled to make use of their bundle of rights. A wide range of property interests can be subject to a de

R.S.O. 1990, c. M-14. The amendments will come into force upon proclamation.

An Act with respect to land use planning and protection in the Far North, 1st Sess., 39th Leg., Ontario, 2010 [Far North Act, 2010].

Government of Ontario, "Far North Ontario,” online: Ministry of Natural Resources <http://www.mnr. gov.on.ca/en/Business/FarNorth/index.html>. 
facto expropriation including intangibles and chattel interests (Manitoba Fisheries and Rock Resources).

(2) Some of the rights in the bundle may be restricted by government regulation.

Not every interference with aspects of property ownership will amount to a compensable de facto expropriation (Nilsson), but this must be done transparently to manage the reasonable expectations of property owners.

(3) Restrictions through government regulation will constitute a de facto expropriation where there is:

(a) A government acquisition of a beneficial interest in the property interest or benefit flowing from it.

From a policy perspective, a broad interpretation of "acquisition” and "beneficial interest" should be adopted to include the removal of encumbrances and liabilities in favour of the government, as well as general benefits to the public (Tener, Nilsson, Newcrest Mining, and WMC Resources). The government does not need to make direct use of the owner's property interest in the same manner as the owner would have (Nilsson). This is especially so given that the very nature of a de facto expropriation is likely to give rise to benefits different than the confiscated proprietary interest. Practically speaking, the purpose behind most government actions and regulations is to promote some kind of public benefit. Instead of trying to cast these public benefits as something other than a beneficial interest (as was the case in Canadian Pacific and ICM Agriculture), they should be explicitly recognized as beneficial interests for which the public must pay. Whether the government acquired a proprietary interest to enjoy directly (Manitoba Fisheries), or to promote the public interest (Tener), this does not change the fact that the developer's natural resource interest has been abrogated, which is tantamount to expropriation. Taking a more reasonable approach to what constitutes the acquisition of a benefit will not open the floodgates for de facto expropriation claims because claimants will still need to demonstrate a removal of all reasonable uses of their property interest. However, one party, even if it is in the public good, should not be unjustly enriched at the expense of another.

(b) A removal of all reasonable uses of the property interest.

A partial removal of reasonable uses of a property interest is not sufficient to support a claim for de facto expropriation (Nilsson, Mariner Real Estate, and Canadian Pacific). However, a total loss of economic value should also equate to a removal of "all reasonable uses" (Lucas). Canadian jurisprudence has yet to stretch this far (Mariner Real Estate), but a more prominent role for the loss of economic value would create greater certainty because economic value can be determined more objectively. 
What constitutes a "reasonable use" should be informed by a consideration of reasonable investor-backed expectations (Penn Central). The reasonableness of investor-backed expectations is shaped by (1) whether the claimant operated in a highly regulated industry, (2) whether the claimant was aware of the problem that spawned the regulation at the time it purchased the allegedly taken property, and (3) whether the claimant could have reasonably anticipated the possibility of such regulation in light of the regulatory environment at the time of purchase (Appolo Fuels). Furthermore, uses that are already prohibited by background principles of property and nuisance laws at the time of purchase should not be considered reasonable for the purpose of establishing de facto expropriation (Lingle).

The analysis must focus on the parcel of property rights as a whole (Penn Central and Keystone). Accordingly, de facto expropriation claims involving large bundles of rights (for example, a fee simple interest in land) require very intrusive regulation before all reasonable uses of the property are removed (Mariner Real Estate, Nilsson, and Canadian Pacific). It is easier to demonstrate that government regulation has defeated the claimant's entire proprietary interest for smaller bundles of rights (Tener, Casamiro, Rock Resources, and Pennsylvania Coal). The range of different natural resource interests is diverse, but generally they are made up of rights specifically related to the exploitation of a particular natural resource. By their very nature, the bundle of rights inherent in natural resource interests are more narrow than those included in fee simple title and, therefore, may make a finding that all reasonable uses have been removed more likely.

(4) An owner of a property interest that was subjected to de facto expropriation will be entitled to compensation unless there is an express statutory abrogation of compensation.

Due to the common law presumption in favour of compensation, the fact that legislation is silent with respect to compensation will not suffice to immunize the government from providing compensation. The amount of compensation will depend on the facts and the applicable regulatory regime or expropriation statute. Generally, compensation is based on the "value to the owner" standard, which is made up of market value and other considerations such as disturbance damages, special value, severance damage and injurious affection, mitigation and abandonment, and interests and costs. Ideally, market value is appraised using the direct sales comparison approach but, where there is a lack of true comparables or reliable statistical data, the cost approach or income approach may also be used.

The amount of compensation awarded will be less when the extent of the natural resource is uncertain. In contrast, where there is reliable data or production records to delineate the natural resource, the risk is lower and a higher amount of compensation should be awarded. Accordingly, the quantum of compensation should correspond with the information or (un)certainty of the value associated with the natural resource interest. 
Property rights, including natural resource interests, have value. This value should not be confiscated for the public interest without the owner having a remedy, such as compensation for the benefit that accrues to the government as a result of the regulation. The government is tasked with upholding the public interest, but the confiscation of property rights for that purpose should not eliminate an entitlement to compensation. Otherwise, the holder of the property right is forced to shoulder a disproportionate cost of the public interest. Compensation for confiscation is consistent with the principles of fairness and justice, and will also provide resource developers and their shareholders with some confidence in the security of their investments in natural resource interests. Not every diminution of property rights is compensable, but a principled approach to de facto expropriation determinations should support credible compensation claims when government regulation prevents developers from developing their natural resource assets. 